previous proposals for a mixture of "major" and "minor" subjects in the sixth form, is that externally examined A-level subjects should be restricted to two, even for intending candidates for university entrance. In addition, the Schools Council proposes that there should be a number of "elective" courses designed by schools to reflect the interests of staff and students and able to support and sometimes complement the remainder of students' work in the sixth form. It is intended that elective subjects should be examined or assessed internally by the schools and not externally by the existing examinations boards. One feature of the proposals is that the Schools Council has outlined ways in which elective studies could form a part of the sixth form curriculum for students not bent on university entrance but who continued to follow courses at Ordinary level instead of at Advanced level. The Schools Council also emphasizes the need somehow to diminish the pressure of competition for university places and much of its concern is with the conditions on which universities may be prepared to give students suitable assurances.

The argument is sustained by statistics which illustrate the changing pattern of the sixth form in British secondary schools. For one thing, for example, the population in the sixth form is growing rapidly, at least as far as can be seen from the increase of the proportion of seventeen year olds staying on at school from $8 \cdot 1$ per cent in 1955 to $11 \cdot 1$ per cent in 1960 and 13.8 per cent in 1965 . At the same time, the proportions of sixth formers not following A-level courses seem to be increasing-the Schools Council has been given access to figures collected by the Inner London Education Authority which show that non-A-level pupils in the first year of the sixth form accounted for 7 per cent of the age group in 1963 and 10.5 per cent in 1967 , only four years later.

\section{Mathematics for the Less Talented}

Much of the current interest in the reform of the school curricula has been concerned with the more talented pupils. In mathematics, the range of experimentation in the United Kingdom is unprecedented, with four large projects in progress, and a number of smaller ones, but again there is a danger that the less talented pupil will be overlooked. The Schools Council has now produced a pamphlet-Mathematics for the Majority, by Mr Philip Floyd--which sets out to remedy the deficiency. (In the introduction he does point out that the Schools Mathematics Project is undertaking a revision of its texts to cater for the less talented, and that the Midlands Mathematical Experiment could be used for below average pupils by extending the time scale.)

The report begins by establishing the greatest limitation to progress-the dismal lack of mathematics teachers in the schools. Because this deficiency does not seem likely to be made good within the next few years, any scheme which is devised has to be appropriate to the teaching talent available-talent which does not always correlate closely with the actual mathematical ability of the teacher. The report suggests a variety of ways in which the interest of children can be sustained by relating the teaching of mathematies to things which they understand, and by the use of equipment-calculating machines, conic sections, equipment for simple surveying-which can help to make mathematics seem less dry and theoretical. Collaboration between mathematics departments and departments of English, history, geography and science can also help to relate arithmetic to real life. The Stock Exchange, opinion polls, wages and systems of payment, old people's budgets, defence costs-all these can be incorporated into a general scheme which brings mathematics to life. "It might be said," $\mathrm{Mr}$ Floyd writes, "that this is, overall, very ordinary mathematics; but these are very ordinary children, and this is the world of mathematics they see around them." But schemes such as this, he emphasizes, do not close the door to the more imaginative mathematical world which the children do not see around them.

Fortunately, the adoption by a number of schools of the Mode II and Mode III forms of examination for the Certificate of Secondary Education enables much more freedom with syllabuses than would otherwise be possible. (In Mode II, the syllabus is determined within the school, but examined outside; in Mode III, the syllabus and the examination are both the responsibility of the school, subject to an external moderator.) This offers a real opportunity for variety, and Mr Floyd makes some suggestions - the mechanics of flight, a study of the computer, the construction of logical circuits, the study of gears, the mathematics of betting and gaming, more respectably called actuarial science. He also provides a series of charts which provide a basis for planning syllabuses. But the final word in the report goes to A. W. Whitehead-"The whole of mathematics consists in the organization of a series of aids to the imagination in the process of reasoning." Teachers, as well as pupils, need these aids to the imagination, Mr Floyd concludes.

\section{Architects}

TALKs are in progress between the Architectural Association and the Imperial College of Science and Technology over the proposed link-up, whereby the AA will become the fourth constituent college of Imperial College. To some, this statement might seem as old as the Albert Memorial, but at last it seems that light is beginning to dawn, and it is hoped that agreement will be reached early in the new year. The University Grants Committee, the third party in the discussions, has agreed to its part of the bargain, which is to provide a recurrent grant, as part of its allocation to Imperial College, for the running of the architectural school. A letter from Sir John Wolfenden to this effect, sent to the AA in August, broke through the deadlock that had been reached. Up to that point, the UGC had promised the grant only if the AA had enough money for the necessary new building in South Kensington, while the AA in its turn felt unable to raise the building money unless the recurrent grant was assured. Now that this part of the problem has been solved it remains to the AA and Imperial College to agree over the building funds. Once the merger has gone through, the AA will cease to be a private institution and will instead be financed by government money, In this way it will be the second private institution of any size that has joined the UGC fold, the other being the Institute of Estate and Farm Management which has just been incorporated into Reading University. 
There may be other private institutes and research centres in Britain that are reflecting on the possibility of becoming part of a university, with the accompanying measurable benefit of government grants, but the UGC seems not anxious to encourage such unions at present, when funds are so limited. There are several architectural schools, for example, at present attached to local authority art colleges, which would dearly love to become university departments. The Leeds school is particularly keen on the idea, but has not so far had much joy from the UGC. When there is not enough money in the kitty to pay for expansion in existing university departments, it is natural that there is reluctance on the part of the UGC to take on extra establishments. When the choice lies between paying fees that would have come from other sources for existing students, and providing money for additional students, the UGC's policy is understandable.

\section{Canadian Research Flourishes}

ThE National Research Council of Canada has spent five times more on scholarships and research in the universities in the past ten years than in the previous forty years of its existence. According to the council's annual report, the sum spent on Canadian universities has risen even in this past decade from $\$ 10.5$ million in 1962 to more than $\$ 35.5$ million last year. Nearly half of this sum is spent on grants and equipment, and the report estimates that, on the average, each professor received $\$ 6,400$ for equipment last year, a thousand dollars more than two years ago. Expenditure on university research is expected to continue to increase.

In 1966, the council established post-industrial experience research fellowships of $\$ 6,000$, to allow engineers and scientists in industry a year for research in government or university laboratories. The scheme is to run for a trial period of two years, five fellows being elected in each year. This year, to celebrate its own golden jubilee and the centenary of Canadian confederation, the council has decided to set up a new group of scholarships. These will be awarded to graduates for research leading to doctorates in universities other than those from which they obtained their first degrees. It is hoped by this means to foster cultural exchange between the different regions of Canada, in the spirit of the centennial year.

\section{Homeless Doctors}

Since the University of St Andrews became independent of Dundee University in October this year, it has been impossible for St Andrews medical students to do their clinical training. Most have continued to go to Dundee for this purpose.

On December 19, however, the university announced that a link-up had been established between $\mathrm{St}$ Andrews and the University of Manchester. From 1973 onwards, preclinical students at St Andrews will go to do their clinical training in hospitals in Manchester, at the United Manchester Hospitals, and also at Withington Hospital, which is being developed into a full teaching hospital. Students at St Andrews will study for three years in the faculty of science on an extended preclinical course leading to a BSc degree, before going to Manchester.
A number of medical schools were approached in the hope of finding accommodation and several were willing to take a few students. The agreement with Manchester, on the other hand, will take the whole output of premedical students. According to Professor A. E. Ritchie at St Andrews, the liaison committee which will operate the scheme will probably be made up of Professor A. C. P. Campbell, Dr F. B. Beswick and Mr A. R. Anscombe representing Manchester, and Professor G. R. Tristram, Professor A. E. Ritchie and Professor R. Walmsley representing St Andrews.

\section{Training Manpower}

LAST week the Ministry of Labour announced a new scheme for the training of craft apprentices in the development areas. The scheme extends the range of training grants already made under the levy and grants system introduced by the Industrial Training Act of 1964. The new grants are of two distinct types; one will provide capital grants towards the cost of providing places for training off the job, and the other will reward employers who take on additional trainees for on-the-job training.

The capital grants, the ministry explains, are intended to encourage the provision of places for training off the job. The ministry will agree with the training boards a standard capital cost for providing the premises and equipment for the training. The employers who provide the new premises will get a grant worth 60 per cent of the cost of providing the places. If the employer can increase the number of training places without building new premises, the grant will be 60 per cent of the costs incurred. Grants of similar scale will be given in industries where there is as yet no recognized form of training. The per capita grant is intended for industries where training is normally done on, rather than off, the job. Employers who make more places available for trainees will be entitled to grants equal to $£ 100$ for each additional trainee.

So far, the industrial training boards cover industries which employ over 10 million people, a figure which will soon be increased to 15 million when new boards, already announced, come into operation. Next year the ministry estimates that some $£ 120$ million will be distributed to individual firms as training grants. The ministry is keen to make the schemes known to more firms, and has produced a pamphlet-Assistance with Industrial Training in the Development Areas (HMSO) -which explains them.

\section{British Aircraft}

THE British Government is now the dominant force in British aviation. There is nothing new in this, of course, but the point has been hammered home with particular emphasis in recent months. First there was the decision to build London's third airport at Stansted, then the apparent dithering over the Concorde, finally the announcement that British Aircraft Corporation would not be allowed to build the BAC 2-11. All these are important commercial decisions, but only in the last is it easy to see why the Government acted as it did. Although BAC wanted to build the 2-11, and British European Airways wanted to fly it, nobody wanted to pay for it. According to Mr Crosland, the President of the Board of Trade, it would have cost $£ 120$ million 